\title{
New aspects in snake venom toxicology
}

\author{
Hermann M. Bolt ${ }^{1}[$
}

Received: 8 April 2021 / Accepted: 28 April 2021 / Published online: 6 May 2021

(C) The Author(s) 2021

Snakebite envenomation causes $>81,000$ deaths and incapacities in another 400,000 people worldwide every year. Snake venoms are complex natural secretions comprised of hundreds of different molecules with a wide range of biological functions, which after injection cause local and systemic toxic manifestations (Di Nicola 2021; Acunha et al 2021).

Against this background, snake venom toxicology is a field of high toxicological impact that has attracted increased interest over the last decade. This is reflected by publications in Archives of Toxicology. Traditionally, toxicologists were primarily interested in snake venom effects on blood coagulation (Klöcking and Hoffmann 1991; Wiwanitkit 2006; Sanchez et al. 2009), a relevant field that continues as an important research matter (Teixeira et al 2011, Giron et al. 2013; Zheng et al. 2013, Sartim et al 2016). Other aspects are cytotoxicity (El Hakim 2011), neurotoxixity (Floriano et al 2019), and immunological effects (Silva da Franca et al. 2021) of snake venom constituents.

The scientific focus of recent articles has broadened, as clinical (Abd El-Aziz et al 2020) and pharmacological matters (Lee et al 2016) were incorporated. The latter aspect is highlighted in current reviews as a cutting-edge topic (Bordon et al 2020; Kalita et al 2021; Akhtar et al 2021). Here, the potential of snake venom constituents for cancer treatment is particularly promising. In this context, progress into identification of constituents of snake venom proteomes is important (Estrella et al 2011; Igci and Demiralp 2012).

The majority of studies have focused on the protein portion (toxins), without paying significant attention to other fractions. A heretofore neglected field is that of lipid constituents of snake venoms. A breakthrough in this new area was just reported in this journal. Acunha et al (2021) reported about an untargeted lipidomic approach, based on liquid chromatography with high-resolution mass spectrometry.

Hermann M. Bolt

bolt@ifado.de

1 Leibniz Research Centre for Working Environment and Human Factors (IfADo), Ardeystr. 67, 44139 Dortmund, Germany
This was applied to investigate the lipid constituents of venoms of the South American snakes Crotalus durissus terrificus and Bothrops moojeni. Phosphatidylcholines (PC), Lyso-PCs, phosphatidylethanolamines (PE), Lyso-PE, phosphatidylserine, phosphatidylinositol, ceramides, and sphingomyelin species were detected. The lipids included bioactive compounds such as platelet-activating factor (PAF) precursor, PAF-like molecules, plasmalogens, ceramides, and sphingomyelins with long fatty acid chain lengths, which may be associated with the systemic responses triggered by Crotalus durissus terrificus and Bothrops moojeni envenomation. The responses include platelet aggregation, activation of intercellular adhesion molecule 1 (ICAM1), apoptosis, as well as the production of pro-inflammatory lipid mediators, cytokines, and reactive species. The new lipidomics aspects will contribute to an increased understanding of the complex pathology elicited by snakebite envenomation.

Funding Open Access funding enabled and organized by Projekt DEAL.

\section{Declarations}

Conflict of interest The author declared not to have actual or potential competing financial interests.

Open Access This article is licensed under a Creative Commons Attribution 4.0 International License, which permits use, sharing, adaptation, distribution and reproduction in any medium or format, as long as you give appropriate credit to the original author(s) and the source, provide a link to the Creative Commons licence, and indicate if changes were made. The images or other third party material in this article are included in the article's Creative Commons licence, unless indicated otherwise in a credit line to the material. If material is not included in the article's Creative Commons licence and your intended use is not permitted by statutory regulation or exceeds the permitted use, you will need to obtain permission directly from the copyright holder. To view a copy of this licence, visit http://creativecommons.org/licenses/by/4.0/. 


\section{References}

Abd El-Aziz TM, Shoulkamy MI, Hegazy AM, Stockand JD, Mahmoud A, Mashaly AMA (2020) Comparative study of the in vivo toxicity and pathophysiology of envenomation by three medically important Egyptian snake venoms. Arch Toxicol 94(1):335-344. https://doi.org/10.1007/s00204-019-02619-y

Acunha T, Nardini V, Faccioli LH (2021) A lipidomics approach reveals new insights into Crotalus durissus terrificus and Bothrops moojeni snake venoms. Arch Toxicol 95(1):345-353. https://doi. org/10.1007/s00204-020-02896-y

Akhtar B, Muhammad F, Sharif A, Anwar MI (2021) Mechanistic insights of sanke venom disintegrins in cancer treatment. Eur J Pharmacol 899:174022. https://doi.org/10.1016/j.ephar.2021. 174022 (Online ahead of print)

Bordon KCF, Cologna CT, Fornari-Baldo EC, Pinheiro-Júnior EL, Cerni FA, Amorim FG, Anjolette FAP, Cordeiro FA, Wiezel GA, Cardoso IA, Ferreira IG, de Oliveira IS, Boldrini-França J, Pucca MB, Baldo MA, Arantes EC (2020) From animal poisons and venoms to medicines: achievements, challenges and perspectives in drug discovery. Front Pharmacol 11:1132. https://doi.org/10. 3389/fphar.2020.01132.eCollection

Di Nicola MR, Pontara A, Kass GEN, Kramer NI, Avella I, Pampena R, Mercuri SR, Dorne JLCM, Paolino G (2021) Vipers of major clinical relevance in Europe: taxonomy, venom composition, toxicology and clinical management of human bites. Toxicology 453:152724. https://doi.org/10.1016/j.tox.2021.152724.Epub

El Hakim AE, Gamal-Eldeen AM, Shahein YE, Mansour NM, Wahby AF, Abouelella AM (2011) Purification and characterization of a cytotoxic neurotoxin-like protein from Naja haje haje venom that induces mitochondrial apoptosis pathway. Arch Toxicol 85(8):941-952. https://doi.org/10.1007/s00204-010-0631-8

Estrella A, Sánchez EE, Galán JA, Tao WA, Guerrero B, Navarrete LF, Rodríguez-Acosta A (2011) Characterization of toxins from the broad-banded water snake Helicops angulatus (Linnaeus, 1758): isolation of a cysteine-rich secretory protein, Helicopsin. Arch Toxicol 85(4):305-313. https://doi.org/10.1007/ s00204-010-0597-6

Floriano RS, Schezaro-Ramos R, Silva NJ Jr, Bucaretchi F, Rowan EG, Hyslop S (2019) Neurotoxicity of Micrurus lemniscatus lemniscatus (South American coralsnake) venom in vertebrate neuromuscular preparations in vitro and neutralization by antivenom. Arch Toxicol 93(7):2065-2086. https://doi.org/10. 1007/s00204-019-02476-9

Girón ME, Rodríguez-Acosta A, Salazar AM, Sánchez EE, Galán J, Ibarra C, Guerrero B (2013) Isolation and characterization of two new non-hemorrhagic metalloproteinases with fibrinogenolytic activity from the mapanare (Bothrops colombiensis) venom. Arch Toxicol 87(1):197-208. https://doi.org/10.1007/ s00204-012-0914-3

Igci N, Demiralp DO (2012) A preliminary investigation into the venom proteome of Macrovipera lebetina obtusa (Dwigubsky, 1832) from Southeastern Anatolia by MALDI-TOF mass spectrometry and comparison of venom protein profiles with
Macrovipera lebetina lebetina (Linnaeus, 1758) from Cyprus by 2D-PAGE. Arch Toxicol 86(3):441-451. https://doi.org/10.1007/ s00204-011-0763-5

Kalita B, Saviola AJ, Mukherjee AK (2021) From venom to drugs: a review and critical analysis of Indian snake venom toxins envisaged as anticancer drug prototypes. Drug Discov Today. https:// doi.org/10.1016/j.drudis.2020.12.21 (Online ahead of print)

Klöcking HP, Hoffmann A (1991) Effects of snake venoms on tissuetype plasminogen activator release. Arch Toxicol Suppl 14:157159. https://doi.org/10.1007/978-3-642-74936-0-31

Lee HL, Park MH, Hong JE, Kim DH, Kim JY, Seo HO, Han SB, Yoon JH, Lee WH, Song HS, Lee JI, Lee US, Song MJ, Hong JT (2016) Inhibitory effect of snake venom toxin on NF-kappaB activity prevents human cervical cancer cell growth via increase of death receptor 3 and 5 expression. Arch Toxicol 90(2):463-477. https:// doi.org/10.1007/s00204-014-1393-5

Sánchez EE, Rodríguez-Acosta A, Palomar R, Lucena SE, Bashir S, Soto JG, Pérez JC (2009) Colombistatin: a disintegrin isolated from the venom of the South American snake (Bothrops colombiensis) that effectively inhibits platelet aggregation and SK-Mel-28 cell adhesion. Arch Toxicol 83(3):271-279. https://doi.org/10. 1007/s00204-008-0358-y

Sartim MA, Costa TR, Laure HJ, Espíndola MS, Frantz FG, Sorgi CA, Cintra AC, Arantes EC, Faccioli LH, Rosa JC, Sampaio SV (2016) Moojenactivase, a novel pro-coagulant PIIId metalloprotease isolated from Bothrops moojeni snake venom, activates coagulation factors II and X and induces tissue factor up-regulation in leukocytes. Arch Toxicol 90(5):1261-1278. https://doi.org/10.1007/ s00204-015-1533-6

Silva de França F, Gabrili JJM, Mathieu L, Burgher F, Blomet J, Tambourgi DV (2021) Bothrops lanceolatus snake (Fer-delance) venom triggers inflammatory mediators' storm in human blood. Arch Toxicol 95(3):1129-1138. https://doi.org/10.1007/ s00204-020-02959-0

Teixeira SS, Silveira LB, da Silva FM, Marchi-Salvador DP, Silva FP Jr, Izidoro LF, Fuly AL, Juliano MA, dos Santos CR, Murakami MT, Sampaio SV, da Silva SL, Soares AM (2011) Molecular characterization of an acidic phospholipase $\mathrm{A}(2)$ from Bothrops pirajai snake venom: synthetic C-terminal peptide identifies its antiplatelet region. Arch Toxicol 85(10):1219-1233. https://doi. org/10.1007/s00204-011-0665-6

Wiwanitkit V (2006) Thrombin-like effect of an important green pit viper toxin, albolabrin: a bioinformatic study. Arch Toxicol 80(12):829-832. https://doi.org/10.1007/s00204-006-0108-y

Zeng F, Shen B, Zhu Z, Zhang P, Ji Y, Niu L, Li X, Teng M (2013) Crystal structure and activating effect on RyRs of AhV_TL-I, a glycosylated thrombin-like enzyme from Agkistrodon halys snake venom. Arch Toxicol 87(3):535-545. https://doi.org/10.1007/ s00204-012-0957-5

Publisher's Note Springer Nature remains neutral with regard to jurisdictional claims in published maps and institutional affiliations. 